\title{
NATIONAL EDUCATION ISSUES IN BOBUR'S WORKS MORALITY AND PERFECTION
}

\author{
Dilorom Adilova
}

Researcher Tashkent State Pedagogical University Named After Nizami, Uzbekistan

\section{ABSTRACT}

Uzbekistan is a land of great scientists who have made a great contribution to world civilization and development. Today, the use of the wise teachings of our ancestors is important in strengthening the spiritual and moral education of our students. Our traditions of kindness, patriotism and human qualities serve as spiritual nourishment to the minds and consciousness of young people.

KEYWORDS:- Babur, national, upbringing, matter, morality, perfection.

\section{INTRODUCTION}

It is an honorable task to educate young people in the spirit of devotion to the motherland, to form in them the qualities of initiative, devotion and morality, based on the program idea "From national revival to national progress" based on the principles of kindness and humanity. The intensity of the new era puts its own clear, firm demands on the education system as well.

Indeed, the enjoyment of the spiritual and moral values of our thinkers in education is the basis for their future growth as a harmoniously developed generation.

\section{THE MAIN RESULTS AND FINDINGS}

From time immemorial, humanity has dreamed of a happy life, a noble society. He condemned injustice, oppression and violence. Ordinary people fought for social justice, equality and friendship between people, happiness. For centuries, man has not only tried to know the nature around him, but also to determine his place and status in society, to understand and solve various problems in life. Science, enlightenment and education were considered to be the main conditions for human perfection and the development of the nation. The lives and works of great people in particular were a model school for them. One of such great figures is the king and poet, scholar and thinker, calligrapher and commander Zahiriddin Muhammad Babur. $\mathrm{He}$ is one of the leading figures in the sociopolitical, scientific and cultural spheres of human history. During his short life, Babur left a great literary and scientific legacy. Scientific and artistic works of the poet, such as "Boburnoma", "Aruz risolasi", "Hatti Boburiy", "Mubayyin", "Risolai volidiya" (translation) have survived.

In Babur's work, the longing for the homeland and the grief of exile, the joy of victories and the 
world of defeats found their bright artistic expression. He shook his pen about the experiences he had seen, experienced, experienced, and excited himself. He did not hide anything in front of the reader, but poured out his heart.

Babur tried to solve many complex issues in life, especially the conflicting truths of human destiny, from Navoi's point of view, inspired by Navoi's works.

Yod etmas emish kishini g'urbatda kishi, Shod etmas emish ko'ngulni mehnatda kishi.

Ko'nglum bu g'ariblikda shod o'lmadi,oh,

G'urbatda sevinmas emish albatta kishi.

Although Babur described his situation in this rubai, scholars have correctly noted that this famous rubai of Alisher Navoi influenced his writing:

G'urbatda g'arib shodmon bo'lmas emish,

El anga shafiqu mehribon bo'lmas emish.

Oltin qafas ichra gar qizil gul butsa,

Bulbulg'a tikandek oshiyon bo'lmas emish.

Babur, on the other hand, wrote that he felt like a "nightingale" in a "golden cage" in a foreign land.

It is known that Babur's book "Risolai-aruz" shows him as a great scholar of oriental poetry, a great theorist. Navoi scholar Abdurashid Abdugafurov notes that while preparing to write the Risolai-aruz, Babur first turned to Navoi's experience. He diligently studies his Mezon ulAvzon, as well as his lyrical heritage. In the process, as he testified in the Boburnoma, he compiled a special collection from the divisions of Khazayn ul-Maoniy ... It should be noted that while writing his work, Babur referred to Navoi more than two hundred times, more than one hundred and sixty times. the matla cites four whole gazelles as examples".

Like all mature poets and writers, Babur was interested not only in the fate of an individual, but also in the spiritual and moral life of the whole nation. At the same time, the poet seeks to evaluate ideas and concepts of national content in terms of universal values.

While Babur repeatedly discusses love in his rubai, on the basis of this feeling, dozens of qualities such as nobility, generosity, generosity, devotion also emphasize the fact that they are deeply rooted in the human heart. In Babur's view, devotion to the land has the same meaning as devotion to the most sincere, purest feelings in the heart. In addition, an extremely exemplary and important aspect of Babur's rubai is that they depict the love of the homeland, that is, the love of the homeland in harmony.

Ko'pdin berikim yoru diyorim yo'qtur.

Bir lahzau bir nafas qarorim yo'qdur.

Keldim bu sori o'z ixtiyorim birla

Lekin borurimda ixtiyorim yo'qtur.

The poet also describes this "involuntaryness" as a "cage of exile" and describes in pain and sorrow the hardships and tortures of the human soul:

Hijron qafasida jon qushi dam qiladur,

G'urbat bu aziz umrni kam qiladur.

Or:

Hijron g'amidan zaif jonim so'ldi, 
CURRENT RESEARCH JOURNAL OF PEDAGOGICS 2(9): 92-96, September

2021 DOI: https://doi.org/10.37547/pedagogics-crjp-02-09-21

ISSN 2767-3278

(C)2021 Master Journals

\section{Crossref dof 80 Google}

Accepted 25th September, 2021 \& Published 30 ${ }^{\text {th }}$ September, 2021

G'urbat alami birla ichim qon to'ldi.

Sometimes it is difficult to distinguish between the rubai and the hijrah or the loss of the homeland. The poet wrote many rubai, especially in distant lands, longing for his homeland. An important aspect is that the poet is also inspired by Alisher Navoi's quartets in expressing his inner pain and suffering:

Yuz mehnatu g'am ko'ngluma yetkurdi firoq.

Jonimg'a balovu dard o'qin urdi firoq, When he complained of separation and emigration, Babur seemed to continue:

Andin berikim qasdim uchun turdi firoq,

Yuz dardu alamni menga yetkurdi firoq, he writes.

It is well known that friendship is one of the main qualities that adorn a person's morality and enhance his dignity. The deeper a person understands the meaning of friendship and the more he can put it into practice, the more he can be an example to others. Babur, like love, prioritizes a sense of friendship over many things, including property and the state. $\mathrm{He}$ is also one of the rubai because he believes that the good deeds of the world are advancing and developing because of friendship:

Davlatqa yetib, mehnat elin unutma,

Bu besh kun uchun o'zungni asru tutma

Borg'onni kel emdi yod qilmay, ey do'st,

Borish-kelishingni lutf etib o'ksutma.- he says. The simple statement of meaning in these verses is: 0 brother! Do not forget the poor or needy, even when you are rich and your wealth is abundant. Don't be proud of this world for four or five days. These words have not lost their meaning and educational significance even today. In one of his rubai, Babur states that the frequent gathering of friends is not only a spoil, but also a great state:

Chun gardishi charx budurur, tengri uchun,

Bir-birni necha kun g'animat tutungiz.

Indeed, it is difficult to conceive of the fact that man is dear and precious to man. Therefore, the more a person strives, the higher the hand of goodness, especially goodness, to the world. There is no nation that doubts the power of goodness and its position in the world of life. In this sense, it would not be a mistake to say that goodness is a source of light that illuminates the hearts of the peoples of the world. The poet comes to a firm conclusion in his ghazal, which begins with the verse, "Who has seen, 0 soul, the good of the world?",

Bori elg'a yaxshilig' qilg'ilki, mundin yaxshi yo'qKim, degaylar dahr aro qoldi falondin yaxshilig'.

Well, the trick of this age is that no matter how much evil is done to you, you should do good, because people (future generations) say that good is not evil at all, that goodness always destroys goodness and remembers you with dua (goodness).

Babur calls people to do good, encourages them to acquire knowledge, enlightenment and profession. His views on science and its virtues are expressed in a number of his poems, as well as in the "Boburnoma". For example, the following lines conclude that in order to be knowledgeable, one must seek knowledge and be faithful to knowledge.

Kim yor anga ilm, tolibi ilm kerak,

O'rgangali ilm tolibi ilm kerak!

Men tolibi ilmu tolibi ilme yo'q,

Men bormen ilm tolibi - ilm kerak.

While emphasizing the incomparable importance of science in human life, Babur encourages people to seek knowledge, to strive for it, to 
CURRENT RESEARCH JOURNAL OF PEDAGOGICS 2(9): 92-96, September

2021 DOI: https://doi.org/10.37547/pedagogics-crjp-02-09-21

ISSN 2767-3278

(C)2021 Master Journals

\section{Crossref dof 80 Google}

Accepted 25th September, 2021 \& Published 30 ${ }^{\text {th }}$ September, 2021

enlighten their minds with the light of knowledge. In his view, science cannot be achieved by indifference, but in the acquisition of knowledge it is necessary to have diligence, perseverance, perseverance and the ability to strive for the goal. In this regard, it is noteworthy that Babur's letter to his son Humayun, who did not speak the language fluently, was vague and incomprehensible as a result of his inability to express his thoughts fluently.

Babur always strongly condemns tyranny and says that no one should hurt the heart as much as he can, a sigh from the heart can ruin the world.

According to Babur, one of the worst moral vices in a person is not appreciating good, being ungrateful and greedy, and responding to good with evil. Babur says this with great confidence because of his many experiences: for example, Babur bitterly rebuked Davlatkhan, who had liberated him from the tyranny of Ibrahim Lodhi and had shown him many blessings, for his betrayal of him: "I called you father, I respect you. showed and treated you better than you thought. I saved you and your sons from wandering in the door of the Baluch. I delivered your wives and those in your harem (your family members) from the abode of Abraham. I have bestowed upon you the three karor (beneficial) lands of Tatarkhan. What evil have I done to you, that you will tie two swords to your chest and waist, draw an army and invade our region, and cause such a commotion and conspiracy?".

According to Bobur, one of the worst moral evils in man is indifference, that is, betraying his loved ones to death: We quoted the following lines from the Boburnoma: , abandoned his brother, mother and sister to Malot and fled to the mountains with a few others.

Mabin on behamiyatro hargiz,

Nahohad did ro'y nekbaxti.

Tan osoni guzinad xeshtanro,

\section{Zanu farzand bigzorad ba saxti.}

(Purpose: Do not see such insignificance, he will never see the face of happiness. He rescues his body and leaves his wife and child in a bad condition.)

That is why Babur proudly states that he has objectively stated the content and purpose of his work, in particular, "Boburnoma", without exaggerating the whole truth: "The purpose of what is written is to write true stories. The purpose of this post is to edit a true story statement, not my own description. Because at that time it was decided that the truth of every word should be written and the true statement of every deed should be edited. I have already written if I have seen any good or bad from my father-in-law. If any guilt or virtues have occurred in a relative or stranger, I have edited. Let the reader apologize and the listener not object".

According to Babur, one of the moral flaws in a person is arrogance, especially pride in one's position and disregard for others, and ignorance. It is written in the Boburnoma: "It is a strange calamity at this time. Especially if such arrogance is manifested by those who are at the head of the state, responsible for the fate of the country, it can lead to tragic consequences for the country and the people. Based on the bitter experience of the tragedy that befell the Khurasan state, Babur concludes: His anger and power came from Mirza Muzaffar, who said, "How can I go to him when he is king?" he said. At such a time, when all his brothers were gathered together and formed an alliance and were determined to fight against the enemy like Shaybanikhan, he did not commit such a heinous crime. It is now rumored that he did not come, but all thought it was nonsense".

Babur strongly condemns violence, theft, robbery and greed, and sometimes advocates cruelty to such people. For example, it is noteworthy that one of Bobur's soldiers 
CURRENT RESEARCH JOURNAL OF PEDAGOGICS 2(9): 92-96, September

2021 DOI: https://doi.org/10.37547/pedagogics-crjp-02-09-21

ISSN 2767-3278

(C)2021 Master Journals

\section{Crossref do) 11 Google}

Accepted 25th September, 2021 \& Published 30th September, 2021

punished him for taking a jug of oil.

It should also be noted that although Babur preached that evil should be punished, as a human being he tried to overcome evil with good in his work.

Babur, like Navoi, divides people into good and bad groups, saying that good people are polite, knowledgeable, humble, and serve the people, and bad people are selfish, pragmatic, greedy for wealth, and morally depraved. He encourages people to acquire good qualities:

Xulqingni rost qilg'il har copug'a borsang,

"Ahsanta" der bori el gar yaxshi ot chiqarsang.

According to the thinker, a person should be based on goodness in his life, behavior and manners, everyone should do good to people as much as possible, show kindness and respect, and do good deeds for parents, children and relatives.

\section{Conclusion}

Bobur's unique way of life, full of versatility and life example, can serve as a model and example school for today's youth at the level of universal values. His justice, courage, bravery, courage, ingenuity and wisdom, confidence in the future, not to lose himself in any situation, self-sacrifice to himself and others, devotion to the country, the homeland, a clear sense of belonging to them, children Special attention to education and other aspects can serve for the spiritual and moral education of our contemporaries, including our youth.

After all, Babur's work is extremely rich in virtues, which include inculcating historical truth in the minds of young people, educating them on the basis of high human qualities.

\section{REFERENCES}

1. Zahiriddin Muhammad Bobur. "Boburnoma", “Teacher", 2008. Page 285

2. Hasan Qudratullaev. Bobur's harmony. T .: "Sharq" 2005, B. 26-55.

3. Valixo'jaev B. Life and work of Zahiriddin Muhammad Babur. History of Uzbek literature. Volume 5, Volume III, -T .: 1978, pages 42-48.

4. Ibrahimov. A. The legacy of the Baburids. -T .: Mehnat, 1993.

5. Mahkamov U.H. Ethics lessons. -T .: Fan, 1994.

6. Muslihiddinovna, M. N., \& Fatkhiddinovna, K. S. (2019). The comparative character analysis of farhad and majnun in epic poems by alisher navai. Test Engineering and Management, 81(11-12), 4198-4206.

7. Doniyorov, A. K., \& Karimov, N. R. (2020). An Incomparable Book of a Great Scholar. Bulletin Social-Economic and Humanitarian Research, (6), 63-71.

8. MUKHIDDINOV, M., SULAYMONOV, I., KHASANOVA, M., ASLANOVA, K., \& SHOMURODOVA, S. (2021). Ode genre and ideological-artistic features of erkin vahidov's odes. Journal of Contemporary Issues in Business \& Government, 27(3).

9. Mamed-Zadeh, I. R., Mamed-Zadeh, Z. Z., Makhamatov, T. M., \& Zhigulskaya, D. V. (2021). STRATEGIC SUBSTANTIATIONS ON THE FORMATION OF THE TURKIC MUSLIM CIVILIZATION: AN ORGANIZATIONAL \& CULTURAL PERSPECTIVE. Academy of Strategic Management Journal, 20, 1-5.

10. Mukhiddinov M. (2020). System of Values and Sufis (The Image of Values and Sufis in the First Epics of "Khamsa"). International Journal of Psychosocial Rehabilitation, 24. 